Kampus 4 Universitas Ahmad Dahlan Jl. Ringroad Selatan, Tamanan, Banguntapan, Bantul

Daerah Istimewa Yogyakarta 55191

Telp. : (0274) 563515 Fax. : (0274) 564604

e-mail : ihtifaz@uad.ac.id

Vol. 2, No. 1, Juni 2019, pp. 39-53

ISSN p:2622-4755 e:2622-4798.

DOI: https://doi.org/10.12928/ijiefb.v2i1.787

\title{
Pengaruh Attitude, Sertifikasi Halal, Promosi dan Brand terhadap Purchase Intention di Restoran Bersertifikasi Halal
}

\section{Diah Ayu Legowati ${ }^{1 *}$, Farah Nisa Ul Albab²}

${ }^{1}$ Universitas Indonesia, Jl. Salemba Raya 4, Jakarta, Indonesia

${ }^{2}$ Universitas Gadjah Mada, Yogyakarta, Indonesia

*e-mail: ayuudiahh@gmail.com 


\title{
Pengaruh Attitude, Sertifikasi Halal, Promosi dan Brand terhadap Purchase Intention di Restoran Bersertifikasi Halal
}

\author{
Diah Ayu Legowati ${ }^{1 *}$, Farah Nisa UI Albab² \\ ${ }^{1}$ Universitas Indonesia, Jl. Salemba Raya 4, Jakarta, Indonesia \\ ²Universitas Gadjah Mada, Yogyakarta, Indonesia \\ *e-mail: ayuudiahh@gmail.com
}

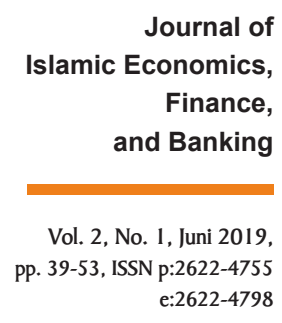

\begin{abstract}
Research related to the purchase intention of halal products has been the concern of many researchers in recent years. This study aimed to determine the relationships between attitude, halal certification, promotion, and brand related to the intention of purchasing at the halal-certified restaurant. The data were collected through a questionnaire survey consisting of 132 consumers. The result showed that the attitude, halal certification, and brand were significantly influential towards the purchase intention at the halal-certified restaurant, whereas a promotion variabele was not significantly influential.
\end{abstract}

Keywords: Attitude, Halal Certification, Promotion, Brand, Purchase Intention

\begin{abstract}
Abstrak
Penelitian ini terkait dengan niat pembelian produk halal yang menjadi perhatian banyak peneliti dalam beberapa tahun terakhir. Penelitian ini bertujuan untuk mengetahui hubungan antara sikap, sertifikasi halal, promosi dan merek terhadap niat membeli di restoran bersertifikasi halal. Data dikumpulkan melalui survei kuesioner yang terdiri dari 132 responden. Hasil penelitian menunjukkan bahwa sikap, sertifikasi halal dan merek berpengaruh signifikan terhadap niat membeli di restoran bersertifikasi halal, sedangkan variabel promosi tidak berpengaruh signifikan.
\end{abstract}

Kata Kunci: Sikap, Sertifikasi Halal, Promosi, Merek, Niat Beli

\section{PENDAHULUAN}

Perkembangan industri Halal sudah sedemikian pesat sampai saat ini mampu menarik perhatian berbagai kalangan. Data dari Global

Ihtifaz: Journal of Islamic Economics, Finance, and Banking 
Islamic Economy Report 2017/2018 menyebutkan indikator tren bisnis Halal terlihat pada lima sektor industri terus menunjukkan kemajuan. IHTIFAZ - JIEFB

Di antaranya adalah jasa keuangan islam, makanan-minuman Halal, wisata Halal, fashion, media dan rekresi Halal, serta farmasi dan kosmetik Halal. Sektor jasa keuangan islam dan makanan-minuman Halal menjadi sektor tertinggi dibandingkan sektor lainya. Nilai belanja makanan dan minuman Muslim di sektor Halal dunia mencapai \$1,24 triliun pada tahun 2016 dan diperkirakan akan naik menjadi \$1,93 triliun pada tahun 2022.

Gaya hidup Halal (Halal lifestyle) belakangan ini memang tengah melanda dunia, tidak hanya terjadi pada negara-negara yang mayoritas berpenduduk muslim tetapi juga di negara berpenduduk mayoritas non muslim. Indonesia sebagai salah satu negara dengan penduduk bermayoritas muslim terbesar dapat dikatakan sebagai pasar yang potensial bagi produk Halal. Berdasarkan Global Islamic Economy Report 2017/2018 Indonesia menjadi konsumen terbesar produk makanan Halal dunia dengan nilai ekonomi mencapai \$169.7 miliar, disusul Turki yang mencapai \$121.1 miliar.

Bagi umat Muslim memang mengkonsumsi produk Halal merupakan sebuah kewajiban. Namun tidak cukup hanya sekedar mengonsumsi makanan yang Halal tapi juga yang baik atau Halal dan thayyib. Halal dan thayyib merupakan syarat utama saat muslim mengonsumsi makanan. Pemahaman umum atas produk Halal haruslah bebas dari bahan yang mengandung babi atau alkohol. Sedangkan hewan, harus disembelih dengan tata cara Islam. Namun seiring dengan perkembangan zaman dan teknologi banyak bermunculan aneka produk olahan makanan yang kehalalannya diragukan. Banyak dari bahan tidak Halal tersebut dimanfaatkan sebagai bahan baku, bahan tambahan atau bahan penolong pada berbagai produk olahan, karena dianggap lebih ekonomis. Akibatnya kehalalan dan keharaman sebuah produk seringkali tidak jelas karena bercampur aduk dengan bahan yang diragukan kehalalannya. Hal ini menyebabkan berbagai macam produk olahan menjadi syubhat dalam arti meragukan dan tidak jelas status kehalalannya. Berdasarkan hal tersebut, maka komisi fatwa Majelis Ulama Indonesia menyimpulkan bahwa semua produk olahan dasarnya adalah syubhat. Oleh karena itu diperlukan kajian dan penelaahan sebelum menetapkan status Halalharamnya suatu produk. Hal ini dilakukan untuk menenteramkan batin umat Islam dalam mengonsumsi suatu produk (HalalMUI.org).

Oleh karena itu, bagi masyarakat muslim memilih makanan Halal itu menjadi hal yang sangat penting terlebih ketika makan disuatu tempat seperti restoran. Restoran merupakan salah satu tempat yang menyediakan makanan dan minuman. Fenomena yang kerap terjadi pada saat ini banyak masyarakat Indonesia terutama di kota-kota besar memiliki kebiasaan makan di restoran. Baik itu ketika hari kerja maupun weekend. Tingginya kebiasaan makan di restoran ini juga 
ditopang dengan pertumbuhan restoran kelas menengah dan atas dalam beberapa tahun terakhir ini.

Namun, pertumbuhan tersebut tidak diiringi dengan kesadaran sertifikasi Halal pada restoran. Di Indonesia, restoran dan cafe belum banyak yang bersertifikat dan baru dalam tataran self claim (Andriani dkk., 2015). Menurut Ikhsan Abdullah, Direktur Eksekutif Indonesia Halal Watch, lembaga resmi yang melakukan advokasi dan perlindungan konsumen untuk mendapatkan produk-produk Halal di masyarakat menunjukkan bahwa dari 3081 restoran yang ada di Indonesia hanya ada 46 restoran $(1,49 \%)$ yang telah memiliki sertifikat Halal dari MUI (Republika.co.id).

Selain itu menurut Ceppy Indra Bestari (pusatHalal.com) dalam artikelnya tentang Urgensi Masyarakat Sadar Halal bahwa masih banyak kaum muslimin yang hampir tidak peduli, menganggap enteng, bahkan cenderung meremehkan kehalalan makanan yang dikonsumsinya. Dapat dilihat ketika pergi ke mall, banyak restoran yang menyajikan makanan modern aneka rupa dan rasa sangat ramai di kunjungi masyarakat. Padahal restoran tersebut belum bersertifikasi Halal, hal ini bisa terlihat di ruangan restoran tidak di dapati pencantuman logo dar LPPOM MUI tentang sertifikasi Halal. Misalnya restoran-restoran yang berasal dari luar negeri seperti dari Italia, Jepang, Korea sangat ramai di kunjungi.

Dengan demikian, dirasa penting untuk melakukan penelitian terkait attitude, sertifikasi halal, promosi dan brand terhadap purchase intention di restoran bersertifikasi halal. Penelitian sebelumnya yang terkait dengan penelitian ini telah banyak dilakukan, namun restoran bersertifikasi Halal yang dijadikan objek penelitian masih jarang dilakukan. Penelitian sebelumnya yang terkait dengan penelitian ini telah dilakukan oleh Aziz dan Chok (2013). Dari hasil penelitianya Halal awarness, Halal certification, marketing promotion dan brand memiliki hubungan yang positif dengan purchase intenton. Sedangkan food quality berhubungan negatif. Secara teoritis, penelitian ini adalah salah satu upaya untuk mengembangkan dan menguji secara empiris model konseptual niat pembelian Halal dengan mengintegrasikan komponen Halal dan yang berhubungan dengan komponen pemasaran.

\section{LANDASAN TEORI}

\section{Purchase intention}

Untuk mengukur niat pembelian, digunakan Theory of Planned Behavior (TPB) dari Ajzen. Purchase intention merupakan sesuatu yang berhubungan dengan rencana konsumen untuk membeli produk tertentu, serta berapa banyak unit produk yang dibutuhkan pada periode tertentu, sehingga dapat dikatakan pula bahwa purchase intention adalah pernyataan mental konsumen yang merefleksikan rencana pembelian sejumlah produk (Barata, 2007). 
Selain itu menurut Assael (2001) purchase intention adalah kecenderungan konsumen untuk membeli sesuatu atau mengambil tindakan yang berhubungan dengan membeli dan diukur dengan tingkat kemungkinan konsumen melakukan membeli. Diukur dengan pernyataan ingin membeli-tidak membeli, akan membeli-tidak akan membeli, akan melakukan membeli ulang-tidak akan melakukan membeli ulang.

\section{Attitude}

Sikap (attitude) merupakan evaluasi dan kecenderungan seseorang yang relatif konsisten untuk bereaksi atau berespon terhadap suatu objek sikap. Terdapat dua hal yang dapat memengaruhi pembentukan sikap, yaitu behavior belief atau penilaian positif atau negatif yang dimiliki seseorang terhadap perilaku dan evaluation of behavioral belief yang merupakan evaluasi positif atau negatif terhadap konsekuensikonsekuensi perilaku yang akan diterima (Ajzen, 2005).

Penelitian oleh Bashir et al., (2018) menunjukkan bahwa terdapat hubungan positif signifikan antara sikap dan intensi untuk membeli produk halal. Lebih lanjut, Bashir et al. (2018) menyatakan bahwa konsumen yang memiliki sikap positif yang tinggi akan memiliki intensi yang lebih tinggi pula untuk membeli produk halal. Hal ini juga sesuai dengan pernyataan Ajzen (1991) bahwa seseorang yang memiliki sikap positif akan melakukan perilaku yang positif pula.

Lada et al., (2009) menyatakan bahwa konsumen lebih cenderung membeli makanan berlabel halal karena sikap positif yang dimiliki oleh konsumen muslim yang berdasarkan keyakinan positif dan kuatnya. Penelitian Elseidi (2018) juga menunjukkan bahwa konsumen muslim yang memiliki sikap yang lebih positif memiliki niat yang lebih besar untuk membeli produk makanan halal tersebut. Hal ini terlihat dari konsumen muslim Arab di Inggirs yang sadar dan memiliki sikap yang kuat dan positif terhadap produk berlabel halal di supermarket Inggris, sehingga berpengaruh positif terhadap niat mereka untuk membeli produk halal tersebut. Sikap tersebut juga dipengaruhi oleh persepsi mereka mengenai implikasi keselamatan dan kesehatan produk (Elseidi, 2018).

\section{Sertifikasi Halal}

Dalam Al-Quran surat Al-Baqarah ayat 168 menyatakan prinsip dasar dari sertifikasi Halal sendiri adalah Halal (diperbolehkan) dan thoyyiban (bermanfaat). Hal ini memberi gambaran untuk umat muslim di dunia bahwa sesuatu yang masuk ke dalam tubuh haruslah sah menurut hukum Islam dan juga bermanfaat bagi dirinya sendiri.

Sertifikasi halal merupakan salah satu faktor yang berperan penting dalam memengaruhi intensi perilaku konsumen di masa depan. Menurut Aziz dan Chok (2013) sertifikasi Halal merupakan jaminan keamanan 
bagi umat muslim untuk dapat mengkonsumsi suatu produk. Sertifikasi Halal ini dibuktikan dengan pencantuman logo Halal pada kemasan produk. Menurut Lada et al., (2009) Produk makanan yang memiliki sertifikasi Halal adalah produk yang didalam proses pengolahannya memenuhi standar dalam keamanan dan kebersihannya. Di Indonesia sertifikasi Halal dikeluarkan resmi oleh MUI yang mengindikasikan bahwa produk sudah lolos tes uji Halal. Produk yang memiliki sertifiksi Halal

Journal of Islamic Economics, Finance, and Banking

Vol. 2, No. 1, Juni 2019 , Pp. 39-53, ISSN p:2622-4755 e:2622-4798 adalah produk yang telah teruji dalam kehalalan dan bisa dikonsumsi umat muslim (HalalMUI.org).

Aziz dan Chok (2013) meneliti intensi konsumen non-muslim dalam membeli produk halal. Hasilnya menunjukkan bahwa sertifikasi Halal memiliki hubungan positif signifikan terhadap intensi untuk membeli produk Halal. Artinya, apabila produk memiliki sertifikasi Halal maka intensi konsumen untuk membeli produk tersebut juga meningkat.

Kualitas pada suatu produk menjadi hal yang sangat diperhatikan oleh konsumen. Sertifikasi Halal merupakan bukti nyata bahwa produk bersertifikasi Halal telah melewati serangkaian tahapan yang terjamin kualitasnya. Konsumen non-muslim menganggap bahwa sertifikasi Halal dapat memberikan pengakuan dan kualitas yang terjamin sehingga mereka bersedia untuk membeli di masa depan (Aziz dan Chok, 2013). Kualitas yang terjamin meliputi kebersihan yang ketat dan praktik-praktik terkait kualitas lainnya (Aziz dan Chok, 2013). Marzuki et al., (2012) juga menyatakan bahwa sertifikasi halal merepresentasikan kepercayaan, keamanan, dan kebersihan terhadap suatu produk dan dianggap sebagai aspek yang penting dalam industri jasa makanan.

Penelitian oleh Marzuki et al., (2012) menunjukkan bahwa manajer restoran memiliki harapan tinggi terhadap sertifikasi halal. Sertifikasi halal dapat memperkuat citra positif restoran. Citra positif dibangun oleh restoran bertujuan untuk menarik minat beli konsumen, sehingga dapat dikatakan bahwa sertifikasi halal dipercaya dapat meningkatkan minat beli konsumen.

Sertifikasi halal juga dapat digunakan sebagai strategi pemasaran kepada pelanggan. Sertifikasi halal sebagai trademark dapat menarik pasar pariwisata (Marzuki et al., 2012). Sertifikasi halal dapat meyakinkan konsumen bahwa produk tersebut halal sehingga berdampak pada permintaan konsumen menginginkan produk makanan yang memiliki logo halal (Awan et al., 2015).

\section{Promosi}

Salah satu cara yang digunakan sebuah perusahaan untuk memasarkan produknya adalah melakukan promosi. Promosi adalah alat yang dapat membantu produsen/pengecer dalam mencapai tujuannya (Alvarez dan Casielles, 2005). Tellis (1998) dalam Kwok dan Uncles (2005) menyatakan promosi terdiri dari promosi penjualan moneter (misalnya diskon harga, kupon, rabat, dan paket harga) dan 
non moneter (misalnya undian, hadiah gratis, dan program loyalitas). Salah satu bentuk promosi adalah pengurangan harga yang dapat IHTIFAZ - JIEFB memberikan pengaruh terbesar pada proses pemilihan brand (Alvarez dan Casielles, 2005). Faktor harga sangatlah penting, karena hal ini dapat menarik pembeli dengan memberikan diskon harga. Promosi memancing dua reaksi diantaranya peningkatan konsumsi, yaitu lebih banyak kuantitas produk diperoleh dan penyimpanan produk untuk masa depan, merupakan tindakan konsumen mengantisipasi pembeliannya (Alvarez dan Casielles, 2005). Berbagai promosi yang telah dilakukan oleh produsen, maka selanjutnya dilakukan penelitian untuk mengetahui dampak dari promosi tersebut. Setelah itu, produsen dapat mengetahui bentuk promosi mana yang lebih efektif (Low dan Mohr, 2000).

Menurut Awan et al., (2015) untuk memasarkan produk makanan halal, memahami perilaku konsumen sangatlah penting. Dengan memahami hubungan antara niat dan faktor penentunya, manajer pemasar dan produsen Halal sebaiknya harus mengetahui bagaimana membangun citra yang menarik dan meningkatkan upaya pemasaran untuk memaksimalkan penjualan dan meningkatkan pangsa pasar mereka. Hasil penelitian Aziz dan Chok (2013) menunjukkan bahwa promosi dapat memengaruhi dan memotivasi konsumen untuk membeli produk Halal. Berbagai strategi pemasaran dapat digunakan oleh perusahaan untuk memasarkan produknya. Misalnya, seperti bagian pemasaran dapat bekerjasama dengan selebriti kemudian merencanakan iklan yang dapat menarik perhatian pembeli agar membeli produk makanan Halal (Awan et al., 2015).

\section{Brand}

Brand didefinisikan sebagai nama yang membedakan dan/atau simbol (seperti logo, merek dagang, atau desain kemasan) untuk mengidentifikasi barang atau jasa dari salah satu penjual atau sekelompok penjualan dan untuk membedakan barang atau jasa tersebut dari kompetitor (Aaker, 1991). Konsumen dapat membedakan barang atau jasa dari brand yang melekat pada perusahaan tersebut. Pemahaman mengenai makna halal seperti yang tercermin pada branding adalah bahwa komoditas, produk dan jasa sesuai dengan ajaran Islam, dan itu diakui oleh standar halal internasional (Lada et al., 2009). Brand Barat menggunakan strategi yaitu sertifikasi halal untuk mempertahankan posisinya dalam konsumsi muslim (Mukhtar dan Butt, 2012). Misalnya, McDonald di Singapura memiliki delapan juta konsumen setahun setelah memperoleh sertifikasi halal (Lada et al., 2009). Hal ini berarti brand yang dibangun oleh sebuah perusahaan akan sangat berpengaruh terhadap minat beli konsumen.

Hasil penelitian (Awan et al., 2015) menunjukkan bahwa intensi konsumen untuk membeli dapat juga dipengaruhi oleh branding produk makanan. Hal ini karena branding sebagai promosi penjualan dan 
mendapat dukungan selebriti (Awan et al., 2015). Dukungan selebriti sebagai bagian promosi dapat menentukan minat beli konsumen di masa depan. Oleh karena itu, penting bagi sebuah produk untuk memiliki branding yang bagus.

Menurut Aziz dan Chok (2013) setiap brand memiliki karakteristik yang berbeda-beda dan konsumen akan memilih brand yang mirip dengan karakteristiknya. Hal ini merupakan persepsi konsumen

Journal of Islamic Economics,

Finance,

and Banking

Vol. 2, No. L, Juni 2019 , Pp. 39-53, ISSN p:2622-4755 e:2622-4798 pada brand tersebut sehingga dapat memberikan pengaruh pada intensi pembelian konsumen. Hasil penelitian Aziz dan Chok (2013) menunjukkan bahwa konsumen memilih brand makanan tertentu dan menunjukkan efek positif pada intensi untuk membeli produk Halal.

\section{Hipotesis}

Berdasarkan uraian di atas, maka hipotesis yang dapat diajukan adalah sebagai berikut:

$\mathrm{H}_{1}$ : Attitude berpengaruh signifikan terhadap intensi konsumen untuk membeli di restoran bersertifikasi Halal

$\mathrm{H}_{2}$ : Sertifikasi halal berpengaruh signifikan terhadap intensi konsumen untuk membeli di restoran bersertifikasi Halal

$\mathrm{H}_{3}$ : Promosi berpengaruh signifikan terhadap intensi konsumen untuk membeli di restoran bersertifikasi Halal

$\mathrm{H}_{4}$ : Brand berpengaruh signifikan terhadap intensi konsumen untuk membeli di restoran bersertifikasi Halal

\section{METODOLOGI PENELITIAN}

\section{Jenis dan Sumber Data}

Pendekatan penelitian yang digunakan dalam penelitian ini adalah pendekatan kuantitatif. Data yang digunakan dalam penelitian ini adalah data primer. Data primer merupakan data yang diperoleh langsung dari sumbernya. Data primer dalam penelitian ini diperoleh melalui survei dengan menyebarkan kuesioner. Bentuk kuesioner yang digunakan adalah close ended questions dan scaled response questions. Close ended questions adalah adalah bentuk pertanyaan atau pernyataan dengan berbagai alternatif respon bagi respondennya guna mengetahui karakteristik responden. Scaled response questions adalah bentuk pertanyaan atau pernyataan yang memakai likert scale guna mengukur dan mengetahui tingkat kepuasan dan ekspektasi konsumen mengenai suatu produk atau jasa yang sedang diteliti, dari sudut pandang konsumen (Rianse, 2008). Terdapat lima tingkatan jawaban dalam kuesioner, yaitu Sangat Tidak Setuju (1), Tidak Setuju (2), Netral (3), Setuju (4) dan Sangat Setuju (5). Setiap responden diminta untuk menunjukkan persetujuan atau ketidaksetujuannya pada setiap 
pernyataan yang diajukan dalam kuesioner. Pernyataan-pernyataan yang digunakan sebagai indikator alam penelitian ini didasarkan pada teori IHTIFAZ - JIEFB dan penelitian terdahulu yang relevan dengan topik penelitian.

\section{Populasi dan Sampel}

Populasi adalah wilayah generalisasi yang terdiri atas subyek yang mempunyai kualitas dan karakteristik tertentu yang ditetapkan oleh peneliti untuk dipelajari dan kemudia ditarik kesimpulanya (Anshori dan Iswati, 2009). Populasi yang digunakan dalam penelitian ini adalah masyarakat muslim Indonesia. Sedangkan sampel adalah bagian yang menjadi obyek yang sesungguhnya dari penelitian tersebut. Penarikan sampel yang digunakan dalam penelitian ini adalah nonprobability sampling yakni purposive sampling. Purposive sampling merupakan satuan sampling yang dipilih berdasarrkan pertimbangan tertentu dengan tujuan untuk memperoleh satuan sampling yang memiliki karakteristik yang dikehendaki. Dimana sampel yang digunakan adalah masyarakat muslim yang berdomisili di Pula Jawa dengan karakteristik pernah ke restoran yang bersertifikasi Halal dalam waktu tiga bulan terakhir. Sampel ini yang dipilih karena dapat mewakili populasi, dimana pada saat ini pertumbuhan restoran di pulau jawa sangat pesat.

\section{Teknik Analisis Data}

Untuk bisa menjawab hipotesis teknik analisis data yang digunakan dalam penelitian ini adalah analisis regresi linier berganda dengan menggunakan perangkat lunak SPSS 25. Dalam melakukan analisis regresi linier berganda, metode ini mensyartakan untuk melakukan uji validitas, uji reliabilitas, dan uji asumsi klasik agar mendapatkan hasil regresi yang baik. Setelah itu baru dilakukan uji hipotesis untuk mengetahui hubungan antar setiap variabel.

\section{HASIL DAN PEMBAHASAN}

\section{Deskripsi Data Penelitian}

Dari penyebaran kuesioner, didapatkan kuesioner yang telah diisi secara lengkap sebanyak 132 kuesioner. Akan tetapi yang sesuai dengan kriteria penelitian hanya sebanyak 104 kuesioner. Dari 104 kueseioner tersebut ketika dilakukan outlier, terdapat 10 kuesioner yang tidak bisa digunakan dalam proses pengolahan data. Sehingga, total kuesioner yang dapat digunakan dalam proses pengolahan data adalah sebanyak 94 kuesioner.

Kuesioner dalam penelitian terdiri atas dua bagian, yakni bagian karakteristik identitas responden dan daftar pernyataan-pernyataan yang dapat mewakili variabel-variabel yang akan diuji. Pertanyaan dibagian karakterisik identitas responden seperti, jenis kelamin, umur, tingkat pendidikan, pekerjaan, status dan pendapatan. Karakteristik responden secara dapat dilihat pada tabel 1 berikut: 
Tabel 1

Karakteristik Responden Penelitian

\begin{tabular}{rrr}
\hline No. Karakteristik Demografi & Jumlah & $\begin{array}{r}\text { Persentase } \\
(\mathbf{\%})\end{array}$ \\
\hline 1. Jenis Kelamin & 25 & 26,60 \\
a. Laki-laki & 69 & 73,40 \\
b. Perempuan & 94 & 100 \\
Total &
\end{tabular}

2. Umur
a. $18-22$
22
b. $23-27$
c. $28-32$
69
3
94
23,40
73,40
3,20
100

Total

3. Pendidikan Terakhir
a. SMA
b. Diploma
c. Sarjana
d. Magister
e. Doktor

Total

4. Pekerjaan
a. Wirasawasta
b. Pegawai pemerintah
c. Pegawai Swasta
d. Ibu Rumah Tangga
e. Mahasiswa
f. Lainya

5

Total

5. Status
a. Belum menikah
b. Menikah

$\begin{array}{rr}86 & 91,50 \\ 8 & 8,5 \\ 94 & 100\end{array}$

Total

6. Pendapatan per bulan

\begin{tabular}{rrr} 
a. < Rp 1.000.000 & 20 & 21,28 \\
b. Rp 1.000.000 - Rp 3.000.000 & 39 & 41,49 \\
C. Rp 3.000.000 - Rp 5.000.000 & 21 & 22,34 \\
d. > Rp 5.000.000 & 14 & 14,89 \\
Total & 94 & 100 \\
\hline
\end{tabular}

Sumber: Data diolah (2019)

Ihtifaz: Journal of Islamic Economics, Finance, and Banking
Journal of

Islamic Economics,

Finance,

and Banking

Vol. 2, No. 1, Juni 2019 , pp. 39-53, ISSN p:2622-4755
e:2622-4798 e: $2622-4798$ 


\section{Uji Validitas dan Reliabilitas}

Uji validitas adalah suatu data dapat dipercaya kebenaranya sesuai IHTIFAZ - JIEFB dengan kenyataan. Uji validitas digunakan untuk mengukur sah atau valid tidaknya suatu kuesioner. Suatu kuesioner dikatakan valid jika pertanyaan pada kuesioner mampu untuk mengungkupkan sesuatu yang akan diukur oleh kuesioner tersebut (Ghozali, 2011). Suatu pertanyaan dikatakan valid jika nilai r-terkoreksi $>$ r-tabel dengan $a=5 \%$.

Sedangkan uji reliabilitas adalah alat untuk mengukur suatu kuesioner yang merupakan indikator dari variabel. Suatu kuesioner dikatakan reliabel atau handal jika jawaban seseorang terhadap pertanyaan adalah konsisten dari waktu ke waktu (Ghozali, 2011). Uji reliabilitas dalam penelitian ini menggunakan rumus Cronbach Alpha, untuk mengetahui tingkat reliabilitas instrumen dari variabel sebuah penelitian. Suatu kuesioner dikatakan handal jika nilai Cronbach Alpha $>$ 0,70 (Nunnally,1994 dalam Ghozali, 2011).

Tabel 2

Hasil uji Validitas dan Reliabilitas

\begin{tabular}{|c|c|c|c|c|c|}
\hline Variabel & Pertanyaan & $\begin{array}{c}\text { Koreksi } \\
\text { terkoreksi }\end{array}$ & Validitas & $\begin{array}{c}\text { Alpha } \\
\text { Cronbach }\end{array}$ & Reliabilitas \\
\hline \multirow[t]{4}{*}{ Attitude } & ATT1 & 0,615 & Valid & 0,781 & Reliabel \\
\hline & ATT2 & 0,857 & Valid & & \\
\hline & ATT3 & 0.804 & Valid & & \\
\hline & ATT4 & 0,813 & Valid & & \\
\hline \multirow{4}{*}{$\begin{array}{l}\text { Sertifikasi } \\
\text { Halal }\end{array}$} & $\mathrm{SH} 1$ & 0,746 & Valid & 0,780 & Reliabel \\
\hline & $\mathrm{SH} 2$ & 0,881 & Valid & & \\
\hline & $\mathrm{SH} 3$ & 0,845 & Valid & & \\
\hline & $\mathrm{SH} 4$ & 0,705 & Valid & & \\
\hline \multirow[t]{2}{*}{ Promosi } & PRMS1 & 0,942 & Valid & 0,887 & Reliabel \\
\hline & PRMS2 & 0,958 & Valid & & \\
\hline \multirow[t]{3}{*}{ Brand } & BRND1 & 0,903 & Valid & 0,830 & Reliabel \\
\hline & BRND2 & 0,887 & Valid & & \\
\hline & BRND3 & 0,798 & Valid & & \\
\hline Purchase & PI1 & 0,626 & Valid & 0,895 & Reliabel \\
\hline \multirow[t]{5}{*}{ Intention } & PI2 & 0,819 & Valid & & \\
\hline & PI3 & 0,845 & Valid & & \\
\hline & PI4 & 0,845 & Valid & & \\
\hline & PI5 & 0,879 & Valid & & \\
\hline & PI4 & 0,840 & Valid & & \\
\hline
\end{tabular}

*dibandingkan dengan nilai $r$ tabel $(a=5 \%, d f=92)=0,2028$

Sumber: Output SPSS (2019) 
Berdasarkan tabel di atas, seluruh pertanyaan kuesioner mempunyai nilai r-terkoreksi > 0,2028 dan nilai Cronbach Alpha > 0,70 maka dapat dikatakan seluruh peranyaan kuesioner valid dan reliabel.

\section{Uji Hipotesis}

\section{Tabel 3}

Hasil Analisis Regresi Berganda

Vol. 2, No. 1, Juni 2019 , pp. 39-53, ISSN p:2622-4755 e:2622-4798

\begin{tabular}{lcc}
\hline \multicolumn{1}{c}{ Hipotesis } & P Value & Hasil \\
\hline H1: Attitude $\rightarrow$ Purchase Intention & 0.000 & Signifikan \\
H2: Sertifikasi Halal $\rightarrow$ Purchase Intention & 0.003 & Signifikan \\
H3: Promosi $\rightarrow$ Purchase Intention & 0.659 & Tidak Signifikan \\
H4: Brand $\rightarrow$ Purchase Intention & 0.000 & Signifikan \\
\hline
\end{tabular}

Sumber: Output SPSS (2019)

Tabel 3 menunjukkan arah jalur hipotesis dan tingkat signifikansi. Hasil penelitian menunjukkan bahwa variabel attitude berpengaruh signifikan terhadap terhadap purchase intention di restoran bersertifikasi halal ( $\beta=0.690, p<0.05$ ). Untuk variabel sertifikasi halal juga memiliki pengaruh yang signifikan terhadap purchase intention di restoran bersertifikasi halal $(\beta=0.304, p<0.05)$. Namun, untuk hipotesis 3, tidak berpengaruh signifikan antara promosi dan purchase intention di restoran bersertifikasi halal $(\beta=-0.049, p<0.05)$. Dengan demikian, hipotesis 3 tidak diterima. Hal ini berarti tidak adanya promosi tidak memengaruhi intensi konsumen untuk membeli produk halal. Sedangkan untuk hipotesis 4 menunjukkan bahwa terdapat pengaruh yang signifikan antara brand dan purchase intention di restoran bersertifikasi halal $(\beta=0.586, p<0.05)$. Nilai $\mathrm{R}^{2}$ adalah 0.67 mengindikasikan bahwa 67 persen dari variasi purchase intention dapat dijelaskan oleh variabel attitude, sertifikasi halal, promosi, dan brand, sedangkan 33 persen sisanya dijelaskan oleh variabel lain.

\section{PEMBAHASAN}

\section{Pengaruh Attitude Terhadap Purchase Intention di Restoran Bersertifikasi Halal}

Berdasarkan hasil pengujian regresi menunjukan attitude berpengaruh signifikan terhadap purchase intention di restoran bersertifikasi Halal dan nilai koefisien bertanda positif. Maka semakin tinggi tingkat attitude maka semakin tinggi pula tingkat purchase intention di restoran bersertifikasi Halal. Hasil penelitan ini juga sejalan dengan penelitian Elseidi (2017) yang meneliti tentang faktor penentu 
niat membeli Halal di Inggris. Hasil penelitian menunjukan bahwa sikap merupakan faktor penting dalam memengaruhi niat konsumen Muslim

Selain itu penelitian Lada et al., (2009), tentang memprediksi niat untuk memilih produk Halal menggunakan theory of reasoned action dimana salah satu variabelnya adalah attitude mengatakan bahwa theory of reasoned action adalah model yang valid yang dapat digunakan untuk memprediksi niat ntuk memilih produk Halal. Demikian juga penelitian yang dilakukan Bashir et al. (2018) dan Alam dan Sayuti (2011) bahwa attitude memiliki pengaruh yang signifikan terhadap purchase intention. Menurut Lada et al., (2009) semakin positif sikap seorang konsumen muslim terhadap label sertifikasi Halal pada suatu kategori produk, maka semakin besar kecenderungan konsumen tersebut untuk memeriksa atau mencari informasi tentang sertifikasi Halal produk yang ingin ia beli dan semakin besar pula kecenderungan konsumen tersebut untuk membatalkan pembelian ketika ia mendapat produk tersebut tidak memiliki sertifikasi Halal, terlebih dalam hal memilih tempat makan pasti akan memilih tempat makan yang telah bersertifikas Halal.

\section{Pengaruh Sertifikasi Halal Terhadap Purchase Intention di Restoran Bersertifikasi Halal}

Variabel sertifikasi Halal dinyatakan berpengaruh signifikan dengan purchase intention dengan nilai koefisien regresi positif. Hasil penelitian ini juga sejalan dengan penelitian Aziz dan Chok (2012), penelitian tersebut menemukan bahwa sertifikasi Halal berpengaruh positif terhadap purchase intention. Hal ini mencerminkan bahwa sertifikasi Halal yang dimiliki sebuah restoran sangat menjadi hal yang penting bagi konsumen dalam memilih restoran, konsumen akan mengutamakan membeli di restoran yang jelas-jelas memiliki sertifikasi Halal.

Sertifikasi Halal merupakan sebuah jaminan keamanan yang menandakan suatu produk makanan dapat dikonsumsi atau tidak. Di Indonesia sertifikasi Halal dikeluarkan resmi oleh MUI. Sertifikasi Halal diberikan kepada perusahaan setelah produk dari perusahaan tersebut Iolos uji Halal oleh MUI. Adanya sertifikasi Halal dalam sebuah produk juga akan memberi image positif berupa kepercayaan konsumen terhadap produk tersebut.

\section{Pengaruh Promosi Terhadap Purchase Intention di Restoran Bersertifikasi Halal}

Berbeda dari hasil penelitian Aziz dan Chok (2013), hasil penelitian ini menunjukkan bahwa promosi tidak berpengaruh signifikan terhadap purchase intention di restoran bersertifikasi halal. Adanya promosi oleh restoran bersertifikasi halal misalnya seperti pemberian diskon nyatanya tidak berpengaruh terhadap purchase intention. Seseorang 
yang memiliki pengetahuan yang baik mengenai halal pasti memiliki awareness yang tinggi pula terhadap produk halal dan tentunya akan memengaruhi purchase intention pada produk bersertifikasi halal (Aziz dan Chok, 2013). Oleh karena itu, sudah menjadi kewajiban konsumen muslim untuk mengonsumsi produk halal. Akibatnya, ada atau tidak adanya promosi, maka konsumen tetap mengonsumsi makanan di restoran bersertifikasi halal. Konsumen membeli produk halal bukan

Journal of Islamic Economics, Finance, and Banking

Vol. 2, No. 1, Juni 2019 , pp. 39-53, ISSN p:2622-4755 e:2622-4798 karena promosi semata, namun karena halal sudah menjadi kewajiban mereka.

\section{Pengaruh Brand Terhadap Purchase Intention di Restoran Bersertifikasi Halal}

Brand berpengaruh positif sigifikan terhadap purchase intention di restoran bersertifikasi halal. Hal ini berarti apabila sebuah produk halal memiliki branding yang baik, maka intensi konsumen untuk membeli produk halal juga akan meningkat. Penting untuk memahami dan menganalisis brand konsumen karena hal ini akan berpengaruh terkait strategi pemasaran (Aziz dan Chok, 2013). Oleh karena itu, perusahaan harus menjaga reputasi brand produknya karena brand memiliki peran penting terhadap purchase intention di restoran bersertifikasi halal, seperti hasil dari penelitian ini. Brand merupakan citra maupun status sebuah produk apakah bereputasi baik atau tidak. Apabila sebuah brand memiliki citra yang baik, maka kepercayaan konsumen akan meningkat pada persepsi produk (Aziz dan Chok, 2013).

\section{KESIMPULAN}

Penelitian ini fokus pada attitude, sertifikasi halal dan marekting components terhadap purchase intention di restoran bersertifikasi halal. Marketing components pada artikel ini yaitu promosi dan brand. Artikel ini menunjukkan bahwa attitude, sertifikasi halal, dan brand memiliki pengaruh positif signifikan terhadap purchase intention di restoran bersertifikasi halal. Namun, variabel promosi tidak berpengaruh signifikan terhadap purchase intention di restoran bersertifikasi halal.

Implikasi dari penelitian ini adalah apabila restoran ingin bersaing pada segmen pasar yang lebih luas, maka sertifikasi halal merupakan syarat mutlak yang harus terpenuhi. Jumlah sampel yang terbatas dan variabel promosi ternyata tidak berpengaruh terhadap purchase intention di restoran bersertifikasi halal menjadi keterbatasan penelitian ini. Studi selanjutnya dapat menambahkan faktor-faktor marketing components lainnya seperti advertising dan variabel lainnya yang dapat memengaruhi purchase intention. Penelitian selanjutnya juga dapat menggunakan metode campuran yaitu mengkombinasikan metode kuantitatif dan kualitatif dalam melakukan observasi. 


\section{DAFTAR PUSTAKA}

IHTIFAZ - JIEFB

Aaker, D. A. (1991). Managing Brand Equity. New York: The Free Press.

Andriani, D Akbar. dkk. (2015). Laporan Akhir Kajian Pengembangan Wisata Syariah. Asisten Deputi Penelitian dan Pengembangan Kebijakan Kepariwisataan Deputi Bidang Pengembangan Kelembagaan Kepariwisataan Kementerian Pariwisata.

Anshori, Muslich \& Iswati, Sri. (2012). Buku Ajar Metodologi Penelitian Kuantitatif. Surabaya: Airlangga University Press.

Alam, S.S. \& Sayuti, N.M. (2011). Applying the Theory of Planned Behavior (TPB) in Halal Food Purchasing. International Journal of Commerce and Management, 21(1), 8-20.

Ajzen, I. (1991). The Theory of Planned Behavior. Organizational Behavior and Human Decision Processes, 50, 179-211.

Ajzen, I. (2005). Attitudes, Personality and Behavior. Mapping Social Psychology.

Assael, H. (2001). Consumer Behaviour 6th Edition. Yew York: Thompson Learning.

Alvarez, B. A., \& Casielles, R. V. (2005). Consumer Evaluation of Sales Promotion: The Effect on Brand Choice. European Journal of Marketing, 39(1/2), 54-70.

Awan, H. M., Siddiquei, A. N., \& Haider, Z. (2015). Factors Affecting Halal Purchase Intention Evidence from Pakistan's Halal Food Sector. Management Research Review, 38 (6), 640-660.

Aziz, Yuhanis Abdul, Chok, Nyen Vui. (2013). The Role of Halal Awareness, Halal Certification, and Marketing Components in Determining Halal Purchase Intention Among Non-Muslims in Malaysia: A Structural Equation Modeling Approach. Journal of International Food and Agribusiness Marketing, 25, 1-23.

Barata, D.D. (2007). Pengaruh Penggunaan Strategi Brand Extension pada Repurchase Intention Konsumen. Jurnal Manajemen, 2(1).

Bashir, A. M., Bayat, A., Olutuase, S. O., \& Latiff, Z. A. (2018). Factors Affecting Consumerss Intention towards Purchasing Halal Food in South Africa: A Structural Equation Modelling. Journal of Food Products Marketing.

Elseidi, Reham I. (2018). Determinants of halal purchasing intentions: evidences from UK. Journal of slamic Marketing, 9(1), 167-190

Ghozali, Imam (2011). Aplikasi Analisis Multivariate dengan program IBM SPSS 19. Semarang: Badan Penerbit Universitas Diponegoro

Kwok, S., \& Uncles, M. (2005). Sales Promotion Effectiveness: The Impact of Consumer Differences at an Ethnic-Group Level. Journal of Product and Brand Management, 14(3), 170-186. 
Lada, S., Tanakinjal, G.H., dan Amin, H. (2009) Predicting intention to choose halal products using theory of reasoned action. International Journal of Islamic and Middle Eastern Finance and Management, 2(1), 66-76.

Low, G. S., \& Mohr, J. J. (2000). Advertising VS Sales Promotion: A Brand Management Perspective. Journal of Product and Brand Management, 389-414.

Marzuki, S. Z., Hall, C. M., \& Ballantine, P. W. (2012). Restaurant Manager and Halal Certification in Malaysia. Journal of Foodservice Business Research, 15, 195-214.

Mukhtar, A., \& Butt, M. M. (2012). Intention to Choose Halal Product: The Role of Religiosity. Journal of Islamic Marketing, 3 (2), 108-120.

Rianse, U. (2008). Metodologi Penelitian Sosial dan Ekonomi Teori dan Aplikasi. Bandung: Alfabeta.

Salehudin, I. Dan Mukhlis, B.M. (2012). Pemasaran Halal: Konsep, Implikasi dan Temuan di Lapangan. Dalam Ikatan Alumni FEUI (Ed.), Dulu mendengar sekarang bicara: kumpulan tulisan ekonom muda FEUI (pp. 29-305). Jakarta: LP FE UI

Global Islamic Economy Report 2017/2018 di https://www. salaamgateway.com (akses pada 26 Maret 2019)

Ramadhan, Bilal. (2017). Baru 48 Restoran di Indonesia yang Bersertifikat Halal di https://www.republika.co.id (akses pada 27 Maret 2019)

www.halalMUI.org, diakses pada 26 Maret 2019

www.pusatHalal.com, diakses pada 26 Maret 2019 